\title{
Do beavers improve the habitat quality for Magellanic Woodpeckers?
}

\author{
¿Los castores mejoran la calidad del hábitat para el pájaro carpintero magallánico?
}

\author{
Gerardo E Soto a, Pablo M Vergara a*, Marlene E Lizama a, Cristian Celis b,c, Ricardo Rozzi ${ }^{\text {b,d,eff }}$, Quiterie \\ Duron g, Ingo J Hahn ${ }^{\text {h }}$, Jaime E Jiménez ${ }^{\text {b,d,e,f,i }}$ \\ *Corresponding author: a Universidad de Santiago de Chile, Departamento de Gestión Agraria, \\ Santiago, Chile, pablo.vergara@usach.cl \\ ${ }^{\text {b }}$ Universidad de Magallanes, Parque Etnobotánico Omora, Punta Arenas, Chile. \\ c Universidad de Chile, Facultad de Ciencias Veterinarias y Pecuarias, Santiago, Chile. \\ ${ }^{\mathrm{d}}$ University of North Texas, Sub-Antarctic Biocultural Conservation Program, Denton, Texas, USA. \\ e University of North Texas, Department of Philosophy and Religion Studies, Denton, Texas, USA. \\ ${ }^{\mathrm{f}}$ Instituto de Ecología y Biodiversidad (IEB-Chile), Santiago, Chile. \\ g 109 boulevard de Soult, 75 012, Paris, France. \\ ${ }^{\mathrm{h}}$ University of Münster, Institute of Landscape Ecology, Münster, Germany. \\ ${ }^{i}$ University of North Texas, Department of Biological Sciences, Denton, Texas, USA.
}

\section{SUMMARY}

The effect of the disturbances caused by the American beaver (Castor canadensis), introduced to the Cape Horn Biosphere Reserve, on species of birds that are forest habitat specialists is poorly understood. Using telemetry data, we determined which attributes of abandoned beaver meadows have a strong impact on habitat selection by the Magellanic woodpecker (Campephilus magellanicus). We detected a positive relationship between the woodpecker habitat use and the fraction of old-growth forest located near these meadows. These results suggest that favorable habitat conditions are generated around small meadows with old-growth forest, because they might increase availability of wood-boring larvae.

Key words: American beaver, Campephilus, habitat selection.

\section{RESUMEN}

El efecto que tienen las perturbaciones causadas por el castor norteamericano (Castor canadensis) -introducido en la Reserva de Biosfera Cabo de Hornos- sobre especies de aves especialistas de hábitat forestales es poco conocido. Utilizando datos de telemetría determinamos qué atributos de las castoreras abandonadas tienen una mayor influencia en la selección del hábitat por los carpinteros negros (Campephilus magellanicus). Existe una asociación negativa entre el uso del hábitat por carpinteros y el tamaño de las castoreras, mientras que los carpinteros muestran preferencias por el bosque antiguo ubicado cerca de estas castoreras. Estos resultados sugieren condiciones de hábitat favorables cerca de las castoreras pequeñas y rodeadas de bosque antiguo, probablemente debido a un aumento en la disponibilidad de larvas taladradoras de madera.

Palabras clave: Castor norteamericano, Campephilus, selección de hábitat.

\section{INTRODUCTION}

Woodpeckers are highly sensitive to anthropogenic forest disturbances that cause the loss of their foraging and breeding structures at different spatial scales (e.g., snags or large decaying trees; Lammertink 2004, Bull et al. 2007). Humans can indirectly contribute to the degradation of bird habitats by introducing mammal species that feed on trees and alter forest ecosystems, including feral goats, rabbits, feral cattle, hogs, and beavers (Hahn et al. 2011).

The American beaver (Castor canadensis Kuhl.), introduced to the sub-Antarctic forests of southern South America in the 1940s, is likely to represent one of the most dramatic cases of forest degradation by an invasive species worldwide (Skewes et al. 2006, Anderson et al. 2009).
Beaver ponds flood adjacent forest areas, thus transforming the forest into meadows once the beavers abandon their dams (Anderson et al. 2009). Beaver ponds and meadows have diverse effects on wildlife in sub-Antarctic forests, decreasing the diversity of aquatic organisms and understory plants (Anderson and Rosemond 2007, Anderson et al. 2009). However, the effect of beavers on forest specialist species, such as the endemic Magellanic woodpecker (Campephilus magellanicus King.) is poorly understood. Vergara and Schlatter (2004) reported more intense foraging by woodpeckers within old-growth forest as distance to beaver meadows decreased. Recently, it was determined ${ }^{1}$ that although woodpeckers only occupy

\footnotetext{
Gerardo E Soto et al., unpublished data.
} 
marginally standing dead trees within abandoned beaver meadows, they exhibit a strong preference for forest areas near to these meadows. In the beaver's native range, several woodpecker species have been reported using beaver meadows and their forest boundaries (Lochmiller 1979, Edwards and Otis 1999). These findings suggest that the disturbance generated by beavers may positively influence the quality of adjacent foraging habitat for woodpeckers. The goal of this study is to evaluate the influence that landscape-scale attributes of beaver mea-dows, and their adjacent boundary areas, might have on the habitat selection patterns of Magellanic woodpeckers.

\section{METHODS}

This study was conducted on Navarino Island in the Cape Horn Biosphere Reserve, southern Chile. The study area encompasses a surface of 924 ha, from sea level to an altitude $c a .400 \mathrm{~m}$ a.s.l., centered on the Omora Ethnobotanical Park (54 $57^{\prime}$ S, $67^{\circ} 39^{\prime} \mathrm{W}$ ). Vegetation occurs as a mosaic of Nothofagus spp. forest stands, scrubland patches, beaver meadows, natural wetlands, and peat bogs in the lower areas. Forest stands vary in their composition (including Nothofagus betuloides (Mirb.) Oerst., Nothofagus antarctica Bidr. Egefam, and Drimys winteri J. R. et Forster in moist and flooded areas, as well as N. pumilio in drier and upland areas), age (i.e., old-growth and secondgrowth), and level of human disturbance, including logging, fires, and livestock impacts. American beavers were first discovered on Navarino Island in the 1960s (Sielfeld and Venegas 1980), being currently widespread in almost all watersheds across the island. In the study site, all beaver meadows were areas once covered by ponds (probably for over 10 years), where the ground is partially flooded with scattered standing dead trees and herbaceous species in less humid sites (Anderson et al. 2009) (figure 1).

We used a GPS database of telemetry locations for modeling within home-range habitat selection pattern of Magellanic woodpeckers ${ }^{2}$. Woodpecker locations were determined daily through radio-telemetry by homing-in (unpublished data). Between January and March 2012, we tracked six male woodpeckers from different adjacent families (2-5 individuals per family). We identified and mapped 19 beaver meadows within the study site using high-resolution QuickBird imagery (resolution = $2.4 \mathrm{~m}$ ) and geo-referenced field data (figure 1). As woodpeckers actively use habitats near abandoned beaver meadows (unpublished data), we delimited a buffer of $100 \mathrm{~m}$ around the boundary of each beaver meadow. This buffer area was considered to be ecologically important for woodpeckers given that more than $70 \%$ of kernel utilization values were distributed within such buffers. Using a vegetation cover map and the $95 \%$ kernel home ranges of each individual, we quantified variables characterizing each beaver mea-

Jaime E Jiménez et al., unpublished data. dow and their adjacent areas. We estimated the area of each meadow and the proportion of the buffer occupied by old-growth forest, second-growth forest, and open vegetation (i.e., peat- and scrublands).

We used binomial generalized linear models to assess the selection of buffer areas around beaver meadows by woodpeckers. In these models, each combination of beaver meadow and individual was considered as an independent data record. Thus, habitat use probability was specified as the frequency of telemetry fixes within the buffer in relation to the total fixes recorded within the home range. We did not include fixes within the meadows because only four times $(<1.5 \%$ of data) were woodpeckers recorded in meadows. The relative area of each buffer within the home range was specified as an offset variable in order to control for the availability of these boundary areas. Beaver meadows and individuals were included as random effect factors. Akaike's information criterion (AIC) and weights were used to evaluate the support for competing a priori models.

\section{RESULTS}

We identified three best supported models ( $\triangle \mathrm{AIC}<2$ ), which comprised the $69 \%$ of Akaike weights (table 1). According to the model-averaged coefficients, the proportion of old-growth and secondary forest had a positive effect on the probability of a woodpecker selecting a buffer area, whereas for the proportion of open areas and size of beaver meadows, this effect was negative (table 2). However, only the effects of old-growth forest and meadow area were significant, having importance coefficient values higher than 0.8 (table 2).

\section{DISCUSSION}

Our results suggest that a positive effect of the proximity of beaver meadows on woodpecker preferences is conditioned by the attributes of the habitat adjacent to these meadows. Old-growth forest is disproportionally more used by woodpeckers as its availability increased around beaver meadows. Old-growth forests function as a primary habitat for woodpeckers, and hence the increased foraging activity near the meadows suggests an improvement in habitat quality. Probably, proximity to flooded areas results in microclimatic gradients in soil moisture conditions that under the canopy may favor infestation of individual trees by woodboring insects (Vergara and Schlatter 2004), the main prey of woodpeckers (Short 1970, Ojeda and Chazarreta 2006). Thus, beavers indirectly could improve, at least in the short or medium term, the quality of habitat for woodpeckers. The preference of woodpeckers for areas near small-sized meadows may be a response to better habitat conditions in these sites. Moreover, small-sized meadows represent small discontinuities (gaps) within the old-growth forest, and hence woodpeckers do not need to move large distances to cross these forest gaps. Further, small meadow areas 


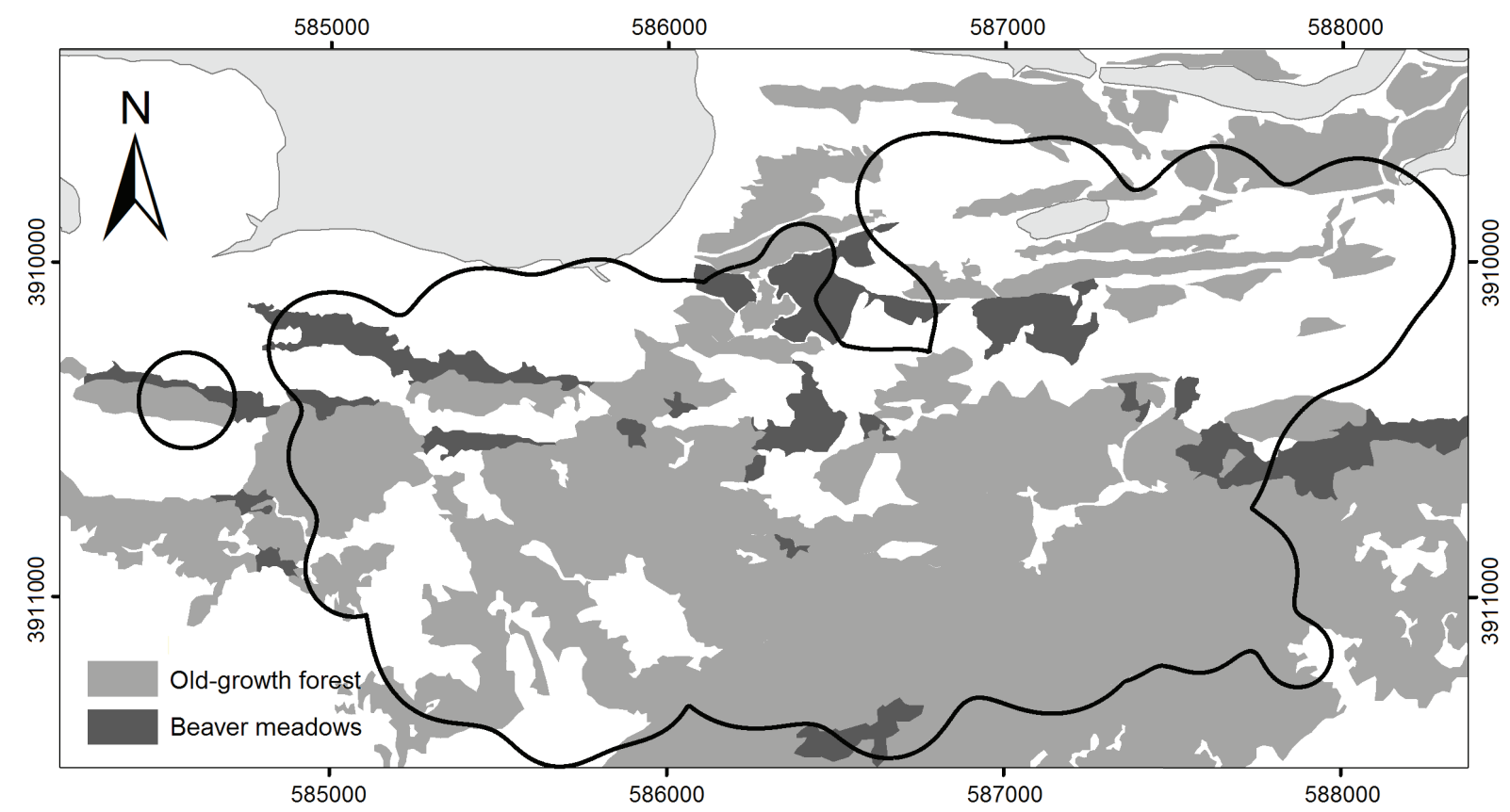

Figure 1. Map of the study area showing the spatial distribution of old-growth forest and beaver meadows in Cape Horn Biosphere Reserve, Navarino Island, Chile. Light grey coloring refers to lakes and sea water. White areas correspond to other cover types (see text). Thick line represents the pooled $95 \%$ kernel home ranges of the six woodpeckers studied.

Mapa del área de estudio que muestra la distribución espacial de los bosques de crecimiento antiguo y las praderas sobre castoreras en la Reserva de Biosfera Cabo de Hornos, Isla Navarino, Chile. El color gris claro representa los lagos y el agua del mar. Las áreas blancas corresponden a otros tipos de cobertura (ver texto). La línea gruesa representa los límites espaciales de los kernels agrupados del 95 \% de los ámbitos de hogar de los seis pájaros carpinteros estudiados.

Table 1. A priori candidate models explaining the selection of buffer areas around beaver meadows by woodpeckers in Navarino Island. Only candidate models with $\triangle \mathrm{AIC}<4$ are shown.

Modelos candidatos a priori que explican la selección de las zonas de amortiguamiento alrededor de castoreras por pájaros carpinteros en la Isla Navarino. Sólo se muestran los modelos candidatos con $\triangle \mathrm{AIC}<4$.

\begin{tabular}{lcccc}
\hline Model & $\mathrm{k}$ & AIC & AAIC & Weight \\
\hline Old-growth forest + Meadow area & 3 & 386.77 & 0.00 & 0.29 \\
Old-growth forest + Secondary forest + Meadow area & 4 & 387.07 & 0.30 & 0.25 \\
Old-growth forest + Open vegetation + Meadow area & 4 & 388.08 & 1.31 & 0.15 \\
Old-growth forest + Secondary forest + Open vegetation + Meadow area & 5 & 389.04 & 2.27 & 0.09 \\
Old-growth forest + Open area & 3 & 389.50 & 2.73 & 0.07 \\
Meadow area & 2 & 390.01 & 3.24 & 0.06 \\
Old-growth forest & 2 & 390.43 & 3.66 & 0.05 \\
Old-growth forest + Secondary forest & 3 & 390.76 & 3.99 & 0.04 \\
\hline
\end{tabular}

Table 2. Model-averaged coefficients, adjusted standard errors, $\mathrm{p}$ values and importance values from models explaining the selection of buffer areas around beaver meadows by woodpeckers in Navarino Island (see table 1).

Coeficientes promediados, errores estándares, valores de probabilidad y valores de importancia de los modelos que explican la selección de las zonas de amortiguamiento alrededor de castoreras por pájaros carpinteros en la Isla Navarino (ver cuadro 1).

\begin{tabular}{lcccc}
\hline Variable & Coefficient & Adjusted SE & $P$ & Importance \\
\hline Old-growth forest & 0.689 & 0.338 & 0.041 & 0.94 \\
Meadow area & $-0.010^{*}$ & $0.005^{*}$ & 0.036 & 0.84 \\
Secondary forest & 0.265 & 0.206 & 0.199 & 0.38 \\
Open vegetation & -0.150 & 0.168 & 0.372 & 0.32 \\
\hline
\end{tabular}

*Multiplied by 1,000 . 
have larger perimeter/area ratios than large meadows and hence, microclimatic conditions suitable for wood-boring insects would increase relatively in buffer areas.

\section{CONCLUSIONS}

Although beavers cause the extensive loss of oldgrowth forest, the primary habitat for Magellanic woodpeckers, they indirectly improve the habitat quality for woodpeckers in Navarino Island. Such an increase in habitat quality could occur due to small beaver meadows provide favorable environmental conditions for the infection by wood-boring insects in Nothofagus spp. trees located near beaver-created habitats.

\section{ACKNOWLEGMENTS}

We thank the Scientific Committee of the 2012 IUFRO Landscape Ecology Conference and the valuable comments by anonymous reviewers. This research has been partially supported by the Sub-Antarctic Biocultural Conservation Program of the University of North Texas (UNT) and the Institute of Ecology and Biodiversity (IEB, P05002 ICM-MIDEPLAN, and PFB-23 Basal-CONICYT). Special thanks to Mario Nazar who supported equipment and travel costs. Jorge Tomasevic provided technical advice, and SAG has provided permits to capture birds. This publication is a contribution to the long-term ecological research program of the Omora Ethnobotanical Park (IEB, UNT, and Universidad de Magallanes) in the Cape Horn Biosphere Reserve.

\section{REFERENCES}

Anderson CB, AD Rosemond. 2007. Ecosystem engineering by invasive exotic beavers reduces in-stream diversity and enhances ecosystem function in Cape Horn, Chile. Oecologia
154(1):141-153.

Anderson CB, G Martinez Pastur, MV Lencinas, PK Wallem, MC Moorman, AD Rosemond. 2009. Do introduced North American beavers Castor canadensis engineer differently in southern South America? An overview with implications for restoration. Mammal Review 39(1): 33-52.

Bull EL, N Nielsen-Pincus, BC Wales, JL Hayes. 2007. The influence of disturbance events on pileated woodpeckers in Northeastern Oregon. Forest Ecology and Management 243(2-3): 320-329.

Edwards NT, DL Otis. 1999. Avian communities and habitat relationships in South Carolina Piedmont beaver ponds. American Midland Naturalist 141(1): 158-171.

Hahn I, PM Vergara, U Römer. 2011. Habitat selection and population trends in terrestrial bird species of Robinson Crusoe Island: habitat generalists vs. forest specialists. Biodiversity and Conservation 20(12): 2797-2813.

Lammertink M. 2004. A multiple-site comparison of woodpecker communities in Bornean lowland and hill forests. Conservation Biology 18(3): 746-757.

Lochmiller RL. 1979. Use of beaver ponds by southeastern woodpeckers in winter. Journal of Wildlife Management 43(1): 263-266.

Ojeda VC, ML Chazarreta. 2006. Provisioning of Magellanic Woodpecker (Campephilus magellanicus) nestlings with vertebrate prey. Wilson Journal of Ornithology 118(2): 251-254

Short LL. 1970. The habits and relationships of the Magellanic Woodpecker. Wilson Bulletin 82(2): 115- 129.

Sielfeld W, C Venegas. 1980. Poblamiento e impacto ambiental de Castor canadensis Kuhl en Isla Navarino, Chile. Anales del Instituto de la Patagonia 36(2): 247-257.

Skewes O, F Gonzalez, R Olave, A Ávila, V Vargas, P Paulsen, HE König. 2006. Abundance and distribution of American beaver, Castor canadensis (Kuhl 1820), in Tierra del Fuego and Navarino islands, Chile. European Journal of Wildlife Research 52(4): 292-296.

Vergara P, RP Schlatter. 2004. Magellanic Woodpecker (Campephilus magellanicus) abundance and foraging in Tierra del Fuego, Chile. Journal of Ornithology 145(4): 343-351. 